\title{
Privatisation of public services in the EU: an attack on social cohesion and democracy
}

\author{
Birgit Mahnkopf
}

Birgit Mahnkopf is Professor of European Politics at the Berlin School of Economics in Germany.

\begin{abstract}
In the past, universal access to essential public services served as an important mechanism for generating a good relationship between the market, social cohesion and democracy in many European countries. But, with the growing dominance of the mode of 'negative integration' across the continent, citizens are being reconstituted as consumers and small shareholders. Meanwhile, privatisation of public services steamrolls the results of the 'decommodification of wage labour' achieved in the short 'social democratic century'. Drawing on the results of the EU-funded Co-ordination Action PRESOM (Privatisation and the European Social Model) this paper argues that in the long run these developments might affect the democratic functioning of the Union and the integration process as a whole. Further information about PRESOM can be found on http://www.presom.eu.
\end{abstract}

\section{Introduction}

The process of privatising public services across Europe is proceeding relentlessly, albeit with major differences from sector to sector and between Eastern and Western Europe. Despite these many variations, a common feature of development can be identified: a regressive process of re-commodification with a parallel development of internationalisation of state functions, ceding at least part of the political control over economic and social development and reducing citizens' political influence over tax expenditures.

In the long run, the privatisation of essential public services seems likely to lead to a continuing deterioration of employment and working conditions in sectors which in the past were characterised by a distinctive 'labour relations regime', providing 'models' which were gradually extended to private industry (Schulten, Brandt \& Herman, 2008, following Corby \& White, 1999). The impacts of privatising and liberalising services in the EU member states could bring even more serious consequences for the future of democratic functioning and, furthermore, the integration process as a whole.

\section{Universal access to 'goods of social value' as an ethical imperative} Until the 1980s, there remained a vital cross-party and even cross-country consensus in the European Union that certain goods and services ought to be excluded from the functioning of the market. European citizens still expected the state to function 
as a necessary and appropriate instrument for social balancing. Public services were perceived as essential for creating and strengthening social cohesion and thus were strongly related to social justice, even if their economic efficiency proved to be lower than under market conditions. This was particularly the case where access to high quality social services and essential utilities were regarded as features of social citizenship. On the other hand, the privatisation of public services, for instance in the USA, was associated with the abandonment of social justice as a political objective, and characteristic of an ideology based on individualism and competition.

The privatisation of utilities like railway networks and postal systems was seen at first as very controversial and, for a long time, the privatisation of 'pure' as well as 'non pure' public goods in terms of welfare economics (goods that are non-rival and non-excludable in consumption) such as water, health care or education was not even a matter for debate. There was a common understanding that the market mechanism is, in principle, not capable of satisfying the needs of all people and cannot guarantee equal living opportunities. Public discourse did not concern itself with the question of public or private provision of public services in terms of economic efficiency nor were education or health care classified as 'services'. These (non pure) public goods were viewed as 'goods of social value' (or 'merit goods') that are indispensable for decent living at a historically given level. Questions regarding the provision, protection, and guarantees of access to these kinds of goods and services were inseparably bound up with the political order as a whole. A broadly shared consensus supposed that policy should enable all citizens to have equal opportunities to realise their individually chosen life plans, and to have access to a range of necessary goods such as water, a healthy environment, safe supplies of energy, good roads, an efficient school system and carefully regulated financial systems. Because in modern society structures of direct solidarity through family, relatives and the neighbourhood have almost died out, the redistribution systems of the welfare state are as important as indispensable goods, because they determine whether a citizen is guaranteed physical and psychological health, knowledge, information or mobility. Against this background, indispensable goods and services had become social rights in the European welfare states of the second half of the twentieth century.

This turned out to be relevant not only for reasons of democratic theory, but also for practical democracy. The quantity and quality of public goods and services are largely open to democratic control. All citizens who know how to organise their interests can influence the direction of money supply (tax revenues and social security income) but citizens may also influence the objectives, structures and expenditure of the institutions which provide services for health care, education, culture or other social services. It is of course true that the existence of these opportunities for public participation does not mean that all citizens make use of them. Nor do public regulation, control and (partial) administration of public services automatically guarantee a higher quality of these services. An improper concentration of power is not ruled out because power can be misused (and here there are many examples) for corrupt individual purposes by politicians and civil servants. However, what is decisive is that, as long as access to public services is a social right, participation in the welfare 
state cannot be reduced to the purchasing power of the population and there are ways and means to realise this basic social right.

Furthermore, the creation of new markets always requires a legal transfer of ownership and the creation of mechanisms to ensure the enforcement of rights. Usually, the conditions for market transactions are set up by a third party, taking the form of 'state legal and political structure'. In the case of services, the social and political constructions necessarily to create new markets, in particular the groups of rights and obligations which have to be specified in order to define the object of exchange, are neither self-evident nor easily created. In the hegemonic (neo-liberal) definition of the economy there is one single argument in favour of privatisation and liberalisation: efficiency. Greater efficiency requires competition, according to this argument. Furthermore, privatisation and liberalisation of services are expected to increase overall quantifiable welfare gains. However, when considering services, economic wealth is not the only good that should be valued. Other non-economic values and social goals (such as equity and social justice or the development of disadvantaged regions) have to be taken into consideration as well. This reflects the legitimacy that is lent to the market through social and cultural forces while legitimacy in the state-society nexus based on historical compromises is also maintained. This situation begs the question of which services can be privatised and liberalised without harming the legitimacy of the state.

In many parts of European public discourse, the model of 'Rhineland capitalism', characterised by extra-market coordination has been confidently set against the US model as an economically successful approach in the context of world-wide competition. Unlike the US model of capitalism, in Europe the state was viewed as the most important agent for protecting citizens against poverty, income inequality and income losses associated with typical labour market risks. Although there were national variations among European welfare regimes, the state stepped in as the ultimate provider of economic and social security. The legitimacy of government was strictly linked to its ability to provide equal access to high quality social services and essential utilities, thereby compensating for the reallocation resulting from market processes through redistribution und regulation. The prevention of wasteful competition between national providers of energy supply, postal, telegraph and telephone systems, the supply and disposal of water, public transportation etc. was an important element of state policy in relation to economic development. Universal access to essential public services served as an important mechanism for generating a good relationship between the market, social cohesion and democracy.

In short, the provision of public services tied democracy to the effective expansion of economic, social, and cultural rights, which were responsive to the values of equality, solidarity and non-discrimination. Over time, the provision of goods and services that particular societies considered should be provided for all their members had been broadened because of the influence they exercised on their capacities or on their welfare. In this context, providing access to 'goods of social value' or 'merit goods' (Musgrave 1959; Atkinson \& Stiglitz 1980; Rodrik 2001), already a reality whenever possible, became an ethical imperative in most European countries. In its 
opposition to the single rationale of economic efficiency, this ethical imperative still persists, although it does so in an increasingly hidden way, in what might be termed the 'subterra' of public discourse in Europe. But it can still be identified, for example in the campaign by the European Public Services Unions (EPSU) for an EU legal framework for services, launched in 2006, which is calling for legal protection that takes public services out of commercialisation and reaffirms the common principle that general interest should take precedence over the laws of the market.

Nevertheless, since the mid 1990s, the wave of global deregulation, liberalisation, and privatisation has overwhelmed even the welfare states of continental Europe. In the Central and Eastern European Countries (CEEC) the transition from socialism to market capitalism has operated in the same direction. In continental Europe the 'new gold rush' started somewhat later than in the USA and UK, where the 'neo-liberal counter-revolution' had already begun in the mid 1970s, and the countries of the Global South, where it was enforced from the 1980s on by means of the structural adjustment programmes of the IMF and World Bank. In Europe, as elsewhere, this development hollowed out what most citizens had until recently experienced as the basic framework conditions for their lives.

The wave of privatisation of services in the EU first started with energy supply and the telecommunications sector. Then it expanded to encompass other service sectors such as public transportation, the postal system, the public building sector, and finally social security institutions and the education sector. Privatisation has gone further than in any other European country in the UK, where even parts of local government, schools and the criminal justice system have now been opened up to private business. Whenever laws and regulations are repealed and public services (including complex processes of interpersonal exchange such as teaching and learning) are treated as a commodity (i.e. as a 'scarce', monetised entity), the same reasons are given - the unavoidable need for reforms in European welfare state provision and the crisis in public finance. Reducing public debt and promoting efficiency are regularly given as justifications when markets (whether in energy, telecommunications, water, health or education) are liberalised or when public enterprises, such as public hospitals, vocational schools, prisons or parts of the military support services, are privatised, or quasi-privatised by means of 'cross-border leasing'. Privatisation seems to be an unavoidable consequence of the interactions between labour market crisis, the fiscal crisis of the state and demographic development.

Since the end of the 'golden age of capitalism' in the mid 1970s, the slow-down of economic growth has continued - with huge losses in state revenues from taxes and social security contributions on the one hand, and increasing state funding of mass unemployment on the other. National debts have increased considerably because their higher expenditures are financed by credit. This situation, which has now persisted for over a quarter of century, has increased the incomes of the already rich, who have in effect lent money to the state and profited from the rise in real interest rates since the 1980s. This context should be borne in mind when considering what specific developments of the late 1980s and 1990s forced privatisation onto the European political agenda. 


\section{The driving forces behind the privatisation of public services in Europe: the transformation of European citizens into market agents}

It is clear that neo-liberal ideology has proven to be a self-fulfilling prophecy which has become a powerful reality in Europe and beyond as a result both of political decisions and non-decisions.

A central role in the privatisation of public enterprises and public services is played by deregulated, global financial markets. Everywhere in the world, real interest rates have been above the real growth rates of GNP. At the same time, there has been a world-wide crisis of overproduction in the consumer goods market. One result of this is that educational and health services have gained in importance. From the point of view of investors, economic areas like the pension and health insurance systems, which offered little scope for reward in the past, now promise to become profitable. It is therefore in their interest of the finance sector that former public goods and services should no longer be financed by taxes and social security contributions, but by interests and profits from the shares and bond markets. In Marxian terms, this is a further development of the so-called 'modernisation of capital'. It can also be described as a massive act of redistribution from the bottom to the top. One result of this method of financing indispensable services is the impoverishment of public finances: the tax base is eroded because an ever-increasing share of the positive surplus funds of the state budget is ending up in the pockets of government bond holders, while revenues continue to decline, partly because of illegal and criminal activities (high tax fraud) as well as dumping mechanisms between the 'competition states'.

In such a situation, privatisation seems to be an obvious, albeit only a short-term instrument for escaping misery. In order to enhance privatisation and advance private investment - in the form of public-private partnerships or foreign direct investment - private property rights have to be put in place. Latterly, WTO agreements have come into play here. especially the TRIPs (Trade-Related Aspects of Intellectual Property rights) and the GATS (General Agreement on Trade in Services). TRIPs lays down a basic procedure for awarding property rights in respect of goods and artefacts that former generations would not have thought possible. The task of GATS is to make liberalisation and deregulation irreversible. Even if the WTO insists that the GATS does not require the privatisation or deregulation of any service, the link that exists between liberalisation and privatisation is an obvious one. While nothing in the text of the Agreement contains a 'prescription to privatise', the mere fact that the goal of GATS is the opening up of markets in the services sector ensures that public enterprises will eventually have to compete with private sector providers. This, in turn, increases pressure on public service providers to deliver services in the same manner as private providers, resulting in a commercialisation of service provision, and, eventually, in privatisation of the public providers. While privatisation and liberalisation are not interchangeable terms, they are certainly fellow travellers. This is not only applicable in the case of the GATS but even more so for the liberalisation policies of the EU.

In the EU the modes of integration encompassed in the single market philosophy have played a vital role in this development, through the parallel processes of deepening and widening and the unbalanced processes of negative and positive integration. 
Deepening and widening of the EU result from both negative and positive integration. Negative market integration demands the dismantling of rules, borders and boundaries in order to liberalise the movement of commodities, services, capital, and human beings. This is the realisation of the 'four freedoms' of the EU, as laid down in its key documents from the Treaty of Rome to the Treaty of Lisbon 2008. This mode of integration obeys both the geo-economic logic of the world market and the geo-political logic of territorial expansion by including different markets and social systems into one single larger market and social system. Hence integration can be understood as a simultaneous process of dismantling borders in the course of spatial expansion and acceleration of capital flows (negative integration) on the one hand and setting up new political limits to ensure the respect of certain rules which are necessary for the smooth working of capitalist accumulation, the creation of a social consensus and the reproduction of political hegemony (positive integration) on the other hand (Altvater \& Mahnkopf 2007).

Negative market integration, which may also be called de facto integration (as distinguished from positive or de jure integration, see Devetak \& Higgot, 2001), is von Hayek's neo-liberal project of a 'constitution of liberty' (Hayek 1944) against any demands for rules of redistribution in order to strengthen the fragile social consensus. This project transforms European citizens into market agents, in the extreme case into the sort of rational constructs embodied in the idea of the homo oeconomicus, even if we add Europaeus as an adjective. A common European identity cannot arise in a crowd of market agents. Tendencies of 'disembedding' (Polanyi 1978), inspired by neo-liberal protagonists, can only be countered where social and economic routines take place in a cultural context where elaborated forms of politically organised coordination can be established and institutions exist to which long-term commitments can be made. Undoubtedly, the opening of borders and removal of other obstacles to the exchange of goods, the movement of people or the flows of capital have brought progress. Negative integration thus has its positive aspects. But these only can be appropriated by EU citizens insofar as the political and social framework is favourable. Without this, the new market liberties can be exploited for ruthless profit-making with negative effects on the natural environment, on the financial order and - most particularly - on labour.

Political and social, and therefore positive integration is essential to avoid negative integration ending in a disaster. Positive integration can be seen as the production of a new legal order, which requires a minimum consensus, and must therefore not only be de facto and de jure, but also de consensu. While negative integration enlarges the private sphere, its contrary (the withdrawal of the state from economic interventions and the entrenchment of the public sphere), namely positive integration, generates the opposite. Positive integration can be seen as the development of a consensus built on the provision of material and immaterial public goods and services. This form of integration could enable Europe to grow with material advantages and future prospects creating 'added value' through this form of integration. But this would require a European regulatory framework that provides equality of access, universality (through the provision of services to all citizens) and accessibility, with price and tariff controls.

In recent decades it is negative integration in the EU that has been predominant, so the formation of a European public space and consent has lagged behind other forms 
of integration. In the course of negative integration, which has de facto extended the 'house of liberties', the positive dimensions of integration have been pushed back. The establishment of an institutional framework for market liberalisation was a precondition for new investment opportunities, resulting in a flood of acquisitions and mergers. At the same time, the integration of markets within Europe resulted in an increasing pressure on competition, pushing private corporations towards the enlargement of their market shares, especially in the Central and Eastern European Countries (CEECs). In addition, the initial effect of the liberalisation of the telecommunications sector and the development of the internet that followed it contributed to the technical and organisational development of other sectors, again fuelling the push for cross-border expansion.

Viewed in this light, privatisation is not an inherent necessity but serves powerful interests. Indeed, it can be seen as a plutocratic attack on essential services, or, as Rosa Luxembourg described it, an 'interior occupation of capitalism' opening up a new stage of global appropriation. This process, which has been described by David Harvey (2003) as 'accumulation by dispossession' does not just raise questions of wages versus profits but concerns goods that are not only indispensable for decent living but also for the protection of basic human rights and sustainable development. This tendency can be illustrated by the case of privatisation in the field of education.

\section{The case of education privatisation: how markets are created}

At the global level, it is international institutions like the World Bank, OECD and WTO that have orchestrated the change in discourse regarding the liberalisation and privatisation of education. The OECD, in particular, has urged the EU to foster competition and cross-border trade and investment in the service sector, including higher education. It promotes private businesses as 'partners for smarter education', examines education systems in order to teach individual countries how to improve their performances 'by learning from each other', and is a promoter of cross-border private investment in higher education (OECD 2007). The GATS is viewed as an exportenhancing agreement for OECD countries largely because of its contribution to the expansion of trade in higher education services.

At the European level, the liberalisation of higher education within the GATS supports and is supported by the so-called 'Bologna Process' which aims to establish a common European Higher Education Area (EHEA). This vehicle is based on a system of easily recognisable and comparable credits and degrees. At present, however, it seems unlikely that the EC will order its member states to open a market in education by constituting education as a 'service of economic interest' (which would bring it within the scope of the provisions that apply to trade in services in the internal market). Thus there appears to be no immediate risk that the member states will face a requirement for liberalisation of (parts of) their national education systems, nor is it likely that education will be included in the Community's GATS negotiations. However, the forms of privatisation that have taken place within the school system in the UK are already included in the EU legislation. If they were to be extended by GATS 'the most likely direction is not the privatisation of state schools but state subsidies to private schools (as 
in Spain and several other European countries' (Hatcher 2006:605). In addition, since 2005 the European Commission has been a driving force of the new hegemonic discourse at the European level. This discourse re-articulates education as a resource for the economy, identifying serious 'gaps' in EU universities, and proposing several 'reforms' to close these gaps to competitors (mainly from the USA). The problems that are supposed to exist in European universities include: a lack of responsiveness to the needs of markets (and society); failure to enable world-class research; and the fact that universities and business still inhabit largely separate worlds. The EC is pressing for 'immediate, in-depth and coordinated change from the way in which educational systems are regulated and managed, to the way in which universities are governed' (EU 2006).

It is against this background that education (in particular higher education) is becoming a part of 'place marketing'. As with other public services, the US higher education system usually serves as a reference model here. Competition, autonomy, lessened state control and free choice of schools according to market parameters will, it is argued, improve education. The introduction of market mechanisms will minimise the costs of education provision. Market forces will generate competition among educational institutions, motivate teachers and academic staff and reduce school and university failure. In short, applying fewer resources and optimising their use will, according to this view, lead to improved performance.

Following this approach, at a national level the member states are organising 'educational reforms' while private actors are using these reforms as specific opportunities for making profits and offering 'solutions' to the 'problems' identified by international organisations, private corporate think tanks and the media (Ball, 2007). In this scenario, the private sector adopts the role of a mediator of policy between the central state and local educational institutions. As a result, the emerging 'European social model' lacks most of the features which in former times distinguished the different European welfare regimes from the US model. It is a model which is promoted by 'missionaries' like the OECD, World Bank, the EC, think tanks and lobby groups representing corporate interests as well as the media. Within this model the role of the state is reduced to that of a contracting party and regulator which buys in preprepared 'good enough solutions' to problems such as budgetary constraints, command bureaucracies and inadequate performance in delivering services. Private corporations, without being legitimised to organise public education, are increasingly providing funding for the public service itself, and even 'selling policies' (ibid).

Private companies can be viewed here as 'mercenaries' making money out of the proliferation of a European social model based on the privatisation of public services by providing a 'good enough', though not 'best', solution for government problems in an age of global competition - offering ever lower corporate taxes, wages and costs for employers. The nation state, including actors in the legislative and the executive branches of the state, is both the object and the subject of a (global) regulatory transformation. And the 'mission' to create a global market for educational services with standards set by European providers is nearly completed, with the UK providing models for private-public partnership in education, a new system of educational governance, closer connections between educational institutions and particular sectors 
of the labour market, and a new role for the private sector as a mediator or even a 'maker' of education policy.

\section{Privatisation of public services as retrogression from rights to contract}

Across Europe, privatisation steamrolls on at a frightening speed bringing with it the 'de-commodification of wage labour' achieved in the short 'social-democratic century' (Hobsbawn, 1994). Even if the degree of de-commodification varies between different European welfare systems, across the continent citizens are being turned into consumers and small shareholders.

With neo-liberal deregulation and privatisation since the mid 1990s, a historically important retrogression from legal to contractual arrangements has been (re)introduced. If the provision, access to and distribution of publicly indispensable goods and services are all regulated through the competitive mechanisms of market economies, then control of these activities is accomplished by contracts between economic actors. Goods and services are thus exchanged through mechanisms of supply and demand. Power and rule are no longer legally regulated and bound, but are the outcome of negotiations between partners, even, if they are unequal partners. Accordingly, power and rule have to be consistently secured, maintained and legitimised.

In neo-liberal terms, control via contracts is superior to hierarchical bureaucratic control. According to this interpretation, freely negotiated contracts widen the opportunities for action and thus provide a fair exchange of different interests among the partners. They can therefore guarantee a greater flexibility for production and enable the dismantling of so called 'crusted' structures. Such arguments play an important role in the debate on public-private partnerships, in other words the areas in which there is long-term co-operation between public and private actors for the fulfilment of public tasks combined with entrepreneurial risk sharing. But the positive results that are anticipated from these contractual relations only appear when power distribution is symmetrical and when the contractual partners know that there is a framework in place for a just balancing of interests. This is why, in the past, the freedom of contract has been limited by putting in place protective laws in favour of the weaker partners in the areas in which asymmetrical power distribution occurs (for instance in labour law or tenancy law).

\section{Impact on social cohesion and democracy}

Within what has been called 'neo-liberal constitutionalism' (Gill 1998), enforceable laws for indispensable goods and services have been subject to disposition - insofar as their production and partly their consumption are re-privatised or transformed into 'club goods' (Altvater 2003). This loss of enforceable laws hollows out the citizenship status of the population and reduces them merely to economic citizens. The homo politicus who has to communicate and organise with others fto obtain his or her rights is reduced to a homo oeconomicus who has almost nothing in common with others. As a customer or a producer or investor each individual strives for his or her own divergent interests. At the same time, the state withdraws from the control and administration of public services. 
In some cases this has resulted in strongly adverse effects on quality, for instance in the privatisation of the British railway system or the problems with energy supply in the USA.

Even more important are the side-effects of deregulation and privatisation of public services for social cohesion and the democratic system as a whole. Effects on social integration and solidarity can be summed up as follows: the more public services are provided by private suppliers, the greater is the danger that the result will be an undersupply of socially and culturally high valued indispensable goods and services for the poorest people. During periods of economic downturn, such effects may spread into the more precarious parts of the middle class. Nonetheless, individualisation is still associated with freedom, efficiency, and self-sufficiency whilst public governance and control are seen as synonymous with state regulation and associated with bureaucracy, waste of public funds, paternalism and control of the individual. It is not surprising, then, that privatisation tendencies in all areas of life are bound up with a pragmatic 'neo-liberalism from beyond'. There seem to be few arguments that can prevail against the insidious charm of slogans like 'more personal responsibilities for the individual' and 'less state'.

Despite this it is generally recognised that the formula of 'personal responsibility' demands self-maintenance by those who lack personal and financial resources and are therefore dependent on handouts from the welfare state. However, at least with regard to social security systems, it is to be doubted whether (re)privatisation will actually lead to any increase in self-maintenance, more efficient use of public funds or growth in individual freedom. The requirement for greater self-determination emerges as a heavy burden for the individual. In financial terms, it can be seen as a redirection of costs at the expense of those whose positions in the workforce are the most precarious. Even employees who earn good money may still feel that the need to purchase private insurance against all risks in life has created excessive financial demands. This has become clear in the USA, where growing numbers of middle-aged employees are attempting to survive without health insurance or a pension scheme, running the risk of dying of curable illnesses or facing impoverishment in old age.

Furthermore, universal self-provision of insurance against job loss, the devaluation of skills or other financial risks (which might at any time be affected by financial and currency crises or by the long-term unemployment that is endemic in capitalist societies) is simply impossible. Unlike state-enforced insurance systems, those that are privately funded cannot generate an increase in self-provision. This is because private providers of public services do not only need to cover their costs but also need to make a profit. They therefore have no choice but to exclude bad risks in order to lower their costs wherever this is possible. In the medium term, this results in two-tier or multi-tier supply systems. People who are judged to be bad risks have to be prepared for big cuts in the quality of services. Privatisation thus contributes not only to a new and deeper social divergence, but will also lead to reductions in the quality of the public goods and services for which the state is still responsible, because these will be produced only for the people in greatest need and thus need not be of high quality: services that are intended mainly for the poor are usually poor services. There will only be pressure for higher standards and optimal supply if access to public services is enabled as a social 
right and is available for all people through their status as citizens, including the wellto-do middle classes.

Educational services represent one of the newest 'gold mines' which has only recently begun to be explored. Here, the impact of marketisation, privatisation and liberalisation may be even more disastrous in terms of both social cohesion and the functioning of democracy. One aspect of this is a change in the priorities and perceived purposes of education. A tendency appears to be emerging to restrict public education to its economic and socio-political functions. Education's function of socialisation and communication is increasingly left to be provided outside the formal education system (by already overloaded families) and the political function of education is almost completely ignored. There is a downplaying of the mediation of ethics, moral obligations, values and behaviours which were formerly considered essential for the orientation of the individual as a fundamental aspect of socialisation. Using the education system to enable individual pupils to understand their democratic civil rights of participation in political decision-making processes becomes seen as less and less relevant. The central focus is increasingly, and selectively, on formal education processes, their linkages to labour market opportunities and the economic value of the so called 'human resources' being 'produced' within education institutions.

In the longer run, there are other impacts of the privatisation of public services that deserve serious attention. It is increasingly the case that important experiences, events and needs in the lives of EU citizens are treated as problems of markets and thus outside the purview of politics. This contributes to the passivity and disengagement of large numbers of people and thus to an erosion of political citizenship. As a result, there is a decline in participation in decision-making, which not only contributes to peoples' well-being but is also the most effective means by which to guarantee that the social aims of development are addressed adequately in public decision-making (see Sen, 1999). Not only will those citizens who are excluded and marginalised from modern employment, consumption and communication processes withdraw from political processes and active citizenship; there will also be a reduction in participation and active engagement in political affairs by those new economic elites who, until recently, performed quite well in the market. We can surmise that while the excluded citizens will react with resignation, and possibly also with anti-democratic rebellion, the new economic elites will regard former public services as 'positional goods' that promise a privileged status (for instance, higher education). Only where their own partial interests are concerned will these people act politically.

According to Albert Hirschman (Hirschman 1970) there are three options available for the articulation and realisation of interests in democratic societies: using 'voice' (opposition) to highlight the undersupply of public services and so react politically; using an 'exit' option (by resorting to alternative suppliers) to satisfy one's needs; and using a 'supply via the market' mechanism by exercising the choice whether to buy or not, or whether to pay or not. This third option is only available for those who have effective monetary purchasing power. These developments mean that the most important of these, voice, is no longer available, leaving only the exit option.

For a democratic society, the difference is essential. Unlike public service providers, private corporations are only accountable to their shareholders, not the citizens of 
the countries they invest in. If a public service provider does not satisfy the needs of its customers, who at the same time are the respective government's electorate, it can be replaced during the next electoral term. But if a private provider, even more so a foreign private provider, fails to satisfy its customers' needs it cannot be held accountable that easily.

\section{Conclusions}

Good arguments for the privatisation of public services are rare. The more comprehensive socio-economic security becomes for all citizens, the less they feel the force of solidarity as an intrusion on personal freedom the greater the societal pressure for maintaining a high quality of indispensable public services becomes.

Certainly, this does not mean that there is no need for reform with regard to Europe as a social union, a project that still could win back citizens' support for European integration. Even a closed defence of solidarity systems for social security need not overestimate the role of the nation states in the Union. Where public services are inefficient and organised in an archaic way, an extension of rights to participation and control by citizens and civil society organisations could address the situation. To some extent, organisational forms of civil society which are 'beyond market and state' can also be seen as alternative means of delivering a publicly or privately organised supply of public services. In many, though not all, cases this could provide a realistic solution. Health, for example, is not only dependent on expensive medical instruments, but can also be improved by bettering working and living conditions. Education, too, can to a certain extent be organised by civil society institutions. Here, the European Social Forum and many other regional and local social groupings and bottom-up self-education activities provide examples. But it is questionable whether the resources of an 'economy of solidarity' would really be sufficient in case of longterm unemployment, serious illnesses or redundancy of skills. Societal institutions like the immediate or extended family, friends, neighbours and voluntary organisations do not offer viable alternatives either, if we take into account that women no longer want to bear the whole burden of care and counselling for a growing number of elderly people. Doubtless, the actors of civil society and social movements have an important contribution to make to public services organised by citizens themselves as third factors between state and private enterprises. But all the new examples of self-organisation that can be observed to be springing up within the framework of a 'economy of solidarity' and which address questions of access to and supply of public services seem to have arisen as a result of destitution rather than spontaneous innovative impulses. Most of these social movements lack the financial resources to develop into an avant-garde anti-neo-liberal movement. An undifferentiated anti-statism which accompanies the criticism of deregulation, liberalisation, and privatisation measures, however valid this critique may be, should not be confused with the necessary but difficult task of bringing a humane society into being.

At a European level it is obvious that positive integration is, to a certain extent, a necessary complement to negative integration and it is therefore necessary to 'throw sand into the transmission' ${ }^{\text {' }}$ of the 'satanic mill' of deregulated markets. This should be

1 This phrase is used by the ATTAC group (see www.attac.org) 
the task of a very different European social model from the one announced at the 2000 Lisbon summit and promoted ever since by the European Commission. If the idea of a European social model is to have any meaning for European citizens, a rebalancing of the EU agenda in favour of social and environmental concerns is of the utmost importance. Both the Lisbon Agenda and the EU service directive (which, through the ambiguities in its wording, opens up even greater scope for the European Court of Justice to rule in favour of greater competition), are being used as crude instruments to attack valid and legitimate social legislation. In order to avoid further disintegration in the EU and a rebirth of nationalism, co-operation must become the driving force of development. This perspective requires public services to be provided in a way that ensures that they maintain a high degree of sociability and solidarity, thereby creating and strengthening social cohesion. However, this cannot be the case if the provision of public services is based on an ideology of individualism and competition.

(C) Birgit Mahnkopf, 2008

\section{REFERENCES}

Altvater, E. \& B. Mahnkopf (2007) Konkurrenz für das Empire. Die Zukunft der Europäischen Union in der Globalisierten Welt, Münster: Westfälisches Dampfboot

Altvater, E. (2003) 'Was Passiert, Wenn Öffentliche Güter Privatisiert Werden? Peripherie, Zeitschrift für Politik und Ökonomie in der Dritten Welt', Vol 23, No 90/91:171-201

Atkinson, A.B. \& J. Stiglitz (1980) Lectures on Public Economics, New York: McGraw-Hill

Ball, S. J. (2007) Education Plc. Understanding Private Sector Participation in Public Sector

Education, London, New York: Routledge

Corbey, S. \& G. White (1999) Employee Relations in the Public Services: Themes and Issues, London:

Routledge

Devetak, R. \& R. Higgot (2001) 'Saving the Social Bond and Recovering the Public Domain' in D.

Drache (ed) The Market or the Public Domain? Global Governance and the Asymmetry of Power,

London \& New York: Routledge:360-380

European Commission (2006) 'Frequently Asked Questions: Why European Higher Education Systems Must be Changed?', Press Releases, May 10, 2006, Brussels. Accessed on January 21, 2008 http://europa.ed/rapid/pressReleasesAction.do/reference=MEMO/06.

Gill, S. (1998) 'European Governance \& New Constitutionalism: EMU \& Alternatives to Disciplinary Neo-Liberalisms in Europe', New Political Economy, Vol 3, No 1:5-26

Harvey, D. (2003) The New Imperialism, Oxford: Oxford University Press

Hatcher, R. (2006) 'Privatization and Sponsorship: The Re-Agenting of the School-System in England', Journal of Education Policy, Vol 21, No 5:599-619

Hayek, F. A. (1944) The Road to Serfdom, London: Routledge

Hobsbawm, E. (1994) Age of Extremes: The Short Twentieth Century, 1914-1991, London: Michael Joseph

Hirschman, A.O. (1970) Exit, Voice and Loyalty, Cambridge: Harvard University Press

Musgrave, R.A. (1959) The Theory of Public Finance, Tokyo: McGraw-Hill

OECD (2007) Education at a Glance. OECD Indicators, Paris: OECD

Polanyi, K. (1978) The Great Transformation, Frankfurt: Suhrkamp

Rodrik, D. (2001) 'Development Strategies for the $21^{\text {st }}$ Century' in Pleskovic \& N. Stern (eds)

Annual World Bank Conference on Development Economics, 2000, Washington, DC: World Bank:85108

Schulten, T,, T.. Brandt \& C. Hermann (2008) 'Liberalisation and Privatisation of Public Services and Strategic Options for European Trade Unions', Transfer, Vol 14, No 2:295-311

Sen, A. (1999) Development as Freedom, New York: Alfred A. Knopf 